\title{
Ultrastructural Changes of Ovaries in Rabbits Following Cadmium Administration
}

\author{
P. MASSÁNYI, V. UHRÍN, R. TOMAN, J. PIVKO ${ }^{1}$, N. LUKÁČ, ZS. FORGÁCS ${ }^{2}$, \\ Z. SOMOSY ${ }^{2}$, M. FABIŠ, J. DANKO ${ }^{3}$ \\ Slovak University of Agriculture, Nitra, \\ ${ }^{1}$ Research Institute of Animal Production, Nitra, Slovak Republic, \\ ${ }^{2}$ Fodor József National Center of Public Health, Budapest, Hungary, \\ ${ }^{3}$ University of Veterinary Medicine, Košice, Slovak Republic
}

Received August 3, 2004

Accepted March 3, 2005

\begin{abstract}
Massányi P., V. Uhrín, R. Toman, J. Pivko, N. Lukáč, Zs. Forgács, Z. Somosy, M. Fabiš, J. Danko: Ultrastructural Changes of Ovaries in Rabbits Following Cadmium Administration. Acta Vet. Brno 2005, 74: 29-35.

Cadmium is an environmental risk factor having various toxic effects both in animals and in humans. The aim of this study was to determine effects of cadmium on the ultrastructure of various ovarian cells in rabbits after an experimental administration. The structure of ovarian cells (granulosa, thecal, stromal, endothelial cells) was analyzed by transmission electron microscopy (TEM).

Animals $(n=24)$ were divided into 3 groups $(K, A, C)$. In group A $(n=8)$ rabbits received cadmium i.p. (1.5 mg. $\mathrm{kg}^{-1}$ body weight) and subsequently were killed $48 \mathrm{~h}$ after administration of cadmium. In group $C(n=8)$ cadmium was administered at a dose of $1.0 \mathrm{mg} \cdot \mathrm{kg}^{-1} \mathrm{~b} . \mathrm{m}$. for $5 \mathrm{month}$ in pelleted food. The last group $(\mathrm{K})$ was the control, receiving no cadmium.

Qualitative analysis of granulosa cells showed undulation of nuclear membrane, dilatation of perinuclear cistern and endoplasmic reticulum. In theca cells dilatation of endoplasmic reticulum was the most characteristic alteration. Also dilatation of perinuclear cistern was evident. In stromal ovarian cells very intensive dilatation of perinuclear cistern and structures with smooth membranes were detected. In endothelial cells dilated mitochondria with altered inner structure, mainly missing cristae were found.

Quantitative analysis of granulosa cells found significant $(p<0.05)$ decrease of relative volume of mitochondria in group $\mathrm{C}$ in comparison with group A. In ovarian thecal cells a significant $(p<0.001)$ increase of the relative volume of endoplasmic reticulum in group A in comparison with control group was detected. In ovarian stromal cells a significant increase of the relative volume of smooth membranes in comparison with control animals was found. In endothelial cells we have observed significantly higher amount of mitochondria and cytoplasm in group A in comparison with control group.

These results describe the fine structural alterations of ovarian cells after administration of cadmium. The negative effect of this common environmental toxicant was detected in all studied cell types and we conclude that it is cell-dependent.
\end{abstract}

Cadmium, ovary, granulosa cells, luteal cells, stromal cells, endothelial cells, organelles

Cadmium is chemically similar to zinc and occurs naturally with zinc and lead in sulfide ores. Some cadmium has been found in all natural materials that have been analyzed. High concentrations in air, water and soil are, however, commonly associated with industrial emission sources, particularly non-ferrous mining and metal refining (Friberg et al. 1986).

In the past, chronic effects due to long-term inhalation of cadmium-containing dust were frequently observed. The type and intensity of symptoms depend on individual disposition as well as on intensity and duration of exposure. Long-term ingestion of large amounts of cadmium has, until now, only been observed in Japan. This has led to kidney dysfunction, as in industrial exposure, and to severe bone disease known as Itai-itai disease (Merian 1991).

Address for correspondence:

Doc. MVDr. Peter Massányi, PhD.

Department of Animal Physiology

Faculty of Biotechnology and Food Sciences

Slovak Agricultural University

Tr. A. Hlinku 2, 94976 Nitra, Slovakia

Phone: +421376508284

Fax: +421 7411210

E-mail:massanyi@yahoo.com

http://www.vfu.cz/acta-vet/actavet.htm 
Cadmium also affects reproductive organs (Massányi and Uhrín 1996, 1997; Massányi et al. 1999, 2000; T oman et al. 2002). Its action may be either direct, affecting the gonads and accessory organs, or indirect via interference with the hypothalamus pituitary - gonadal axis (Paksy et al. 1992; Massányi and Uhrín 1996).

Basic histological studies showed that in the ovary cadmium causes a decrease in the number of primary follicles after i.p. administration. The number of atretic follicles was significantly $(p<0.05)$ higher after cadmium administration. The percentage of growing follicles was significantly higher and that of stroma significantly lower in control group in comparison with all experimental groups receiving cadmium (Massányi and Uhrín 1996). Cadmium chloride administered s.c. induced profound cellular and vascular changes in the ovary of prepubertal rats. The large and medium-size follicles underwent immediate mass atresia and the smaller ones followed after a brief period of resistance (Kar et al. 1959).

The aim of this study was to determine ultrastuctural alterations of ovarian cells (granulosa cells, theca cells, stromal cells, endothelial cells) after an experimental administration of cadmium (i.p. and p.o.).

\section{Materials and Methods}

All experiments were conducted on rabbits (Hyla, Research Institute of Animal Production, Nitra, Slovak Republic). Animals (24) were divided into three groups (K, A, C). Eight rabbits received cadmium i.p. $\left(1.5 \mathrm{mg} \cdot \mathrm{kg}^{-1}\right.$ body mass). These animals (group A: acute effects) were killed $48 \mathrm{~h}$ after administration of cadmium $\left(\mathrm{CdCl}_{2}, \mathrm{Sigma}\right.$, St. Louis, MO, USA). Cadmium was diluted in physiological saline to the appropriate concentration. A chronic experiment (group C: chronic effects) was carried out on the same number of animals. In this group cadmium was administered at a dose of $1.0 \mathrm{mg} \cdot \mathrm{kg}^{-1} \mathrm{~b} . \mathrm{m}$. for $5 \mathrm{month}$ in pelleted food. Food and water were available for all animals ad libitum. The last group $(\mathrm{K})$ was the control, receiving no cadmium.

Ovarian samples were fixed in 2\% paraformaldehyde and $2.5 \%$ glutaraldehyde in $0.2 \mathrm{M}$ phosphate buffer at $4{ }^{\circ} \mathrm{C}$ for $2 \mathrm{~h}$, dehydrated in graded series of ethanol solution, and embedded in epoxy resin. Ultrathin sections were stained with uranyl acetate and lead citrate and observed using JEM - 100 CX-II (JOEL, Japan). From each experiment 20 electron microscopy sections from at least three different replicates were examined.

From photographs based on micromorphological criteria (Weibel et al. 1966; Massányi and Uhrín 1996; Žitný et al. 2004) in all studied cells (granulosa, thecal, stromal and endothelial) these parameters were evaluated: relative volume (\%) of nucleus, mitochondria, endoplasmic reticulum, smooth membranes and cytoplasm; cytoplasm:nucleus $(\mathrm{C}: \mathrm{N})$ ratio.

Analysis of variance and t-test were used to calculate basic statistic characteristics (mean, standard deviation, median, minimum, maximum) and to determine significant differences in structures.

\section{Results}

Qualitative analysis of granulosa cells showed that in experimental groups most frequent alterations are - undulation of nuclear membrane (mainly external), dilatation of perinuclear cistern and endoplasmic reticulum (Plate I, Fig. 1). In theca cells dilatation of endoplasmic reticulum was the most characteristic sign of alterations (Fig. 2). Also dilatation of perinuclear cistern was evident. In stromal ovarian cells very intensive alterations of nuclear membrane (dilatation of perinuclear cistern) and dilated structures with smooth membranes were detected (Plate II, Fig. 3). In endothelial cells dilated mitochondria with altered inner structure, mainly missing cristae were found (Fig. 4). In all studied types of cells mitochondria with altered structure were observed.

Quantitative analysis of granulosa cells found significant $(p<0.05)$ decrease of mitochondria amount in group $\mathrm{C}$ in comparison with group A (Table 1). Also decrease of cytoplasm and increase of nuclear relative volume was detected (decreased $\mathrm{C}: \mathrm{N}$ in cadmium exposed granulosa cells). The relative volume of endoplasmic reticulum was very similar in all groups. In the smooth membranes relative volume we report non-significant decrease of this organelles in both cadmium-exposed groups.

In ovarian thecal cells a significant $(p<0.001)$ increase of the relative volume of endoplasmic reticulum in group A in comparison with control group was detected. Relative 
volume of nucleus was increased in both experimental groups, but the $\mathrm{C}: \mathrm{N}$ ratio was weakly decreased only in group A. In both Cd-exposed groups the relative volume of mitochondria was lower than in control group. Opposite image was detected in smooth membranes (Table 2).

Table 1. Morphometric parameters of the ovarian granulosa cells

\begin{tabular}{|c|c|c|c|c|c|}
\hline & $\mathrm{x}(\%)$ & $\mathrm{s}$ & median & $\min$ & $\max$ \\
\hline \multicolumn{6}{|c|}{ Group K (control) } \\
\hline Nucleus & 37.22 & 13.87 & 40.50 & 6.96 & 51.36 \\
\hline Mitochondria & 2.18 & 0.51 & 2.15 & 1.34 & 3.04 \\
\hline Endoplasmic reticulum & 1.48 & 1.03 & 1.05 & 0.45 & 3.66 \\
\hline Smooth membranes & 1.28 & 1.21 & 0.90 & 0.36 & 4.21 \\
\hline Cytoplasm & 57.84 & 13.87 & 54.95 & 44.76 & 88.75 \\
\hline Ratio C:N & 2.67 & 3.81 & 1.36 & 0.89 & 12.75 \\
\hline \multicolumn{6}{|c|}{ Group A (i.p. $1.5 \mathrm{mg} \mathrm{Cd} \cdot \mathrm{kg}^{-1}$ ) } \\
\hline Nucleus & 43.22 & 16.00 & 40.69 & 23.47 & 62.77 \\
\hline Mitochondria & 1.83 & 0.50 & 1.89 & 0.94 & 2.39 \\
\hline Endoplasmic reticulum & 1.65 & 1.13 & 1.60 & 0.53 & 3.36 \\
\hline Smooth membranes & 0.76 & 0.31 & 0.61 & 0.53 & 1.21 \\
\hline Cytoplasm & 52.54 & 16.10 & 54.74 & 33.24 & 73.71 \\
\hline Ratio C:N & 1.51 & 1.00 & 1.38 & 0.53 & 3.14 \\
\hline \multicolumn{6}{|c|}{ Group C (p.o. 1.0 Cd·kg-1) } \\
\hline Nucleus & 44.85 & 18.16 & 45.07 & 18.36 & 72.13 \\
\hline Mitochondria & $1.08^{*}$ & 0.32 & 1.20 & 0.56 & 1.47 \\
\hline Endoplasmic reticulum & 1.51 & 0.78 & 1.50 & 0.14 & 2.93 \\
\hline Smooth membranes & 0.54 & 0.50 & 0.53 & 0 & 1.65 \\
\hline Cytoplasm & 52.02 & 18.12 & 51.82 & 26.13 & 78.69 \\
\hline Ratio C:N & 1.62 & 1.39 & 1.16 & 0.36 & 4.29 \\
\hline
\end{tabular}

$* p<0.05(\mathrm{~A}-\mathrm{C})$

Table 2. Morphometric parameters of the ovarian thecal cells

\begin{tabular}{|c|c|c|c|c|c|}
\hline & $\mathrm{x}(\%)$ & $\mathrm{s}$ & median & $\min$ & $\max$ \\
\hline \multicolumn{6}{|c|}{ Group K (control) } \\
\hline Nucleus & 25.67 & 3.94 & 25.67 & 21.73 & 29.61 \\
\hline Mitochondria & 3.12 & 0.22 & 3.12 & 2.90 & 3.33 \\
\hline Endoplasmic reticulum & 0.15 & 0.15 & 0.15 & 0 & 0.29 \\
\hline Smooth membranes & 3.90 & 3.17 & 3.90 & 0.73 & 7.07 \\
\hline Cytoplasm & 67.16 & 0.70 & 67.16 & 66.47 & 67.87 \\
\hline Ratio C:N & 2.66 & 0.44 & 2.61 & 2.24 & 3.12 \\
\hline \multicolumn{6}{|c|}{ Group A (i.p. $1.5 \mathrm{mg} \mathrm{Cd} \cdot \mathrm{kg}^{-1}$ ) } \\
\hline Nucleus & 34.19 & 8.78 & 34.19 & 25.41 & 42.97 \\
\hline Mitochondria & 1.55 & 0.61 & 1.55 & 0.95 & 2.16 \\
\hline Endoplasmic reticulum & $1.69 *$ & 0.20 & 1.69 & 1.49 & 1.89 \\
\hline Smooth membranes & 1.35 & 0.27 & 1.35 & 1.08 & 1.62 \\
\hline Cytoplasm & 61.22 & 8.25 & 61.22 & 52.97 & 69.46 \\
\hline Ratio C:N & 1.92 & 0.76 & 1.79 & 1.23 & 2.73 \\
\hline \multicolumn{6}{|c|}{ Group C (p.o. 1.0 Cd·kg-1) } \\
\hline Nucleus & 31.44 & 13.86 & 31.44 & 17.60 & 45.31 \\
\hline Mitochondria & 1.28 & 0.61 & 1.28 & 0.67 & 1.88 \\
\hline Endoplasmic reticulum & 1.07 & 0.67 & 1.07 & 0.40 & 1.73 \\
\hline Smooth membranes & 0.80 & 0.80 & 0.80 & 0 & 1.60 \\
\hline Cytoplasm & 65.41 & 12.99 & 65.41 & 52.41 & 78.40 \\
\hline Ratio C:N & 2.56 & 1.70 & 2.08 & 1.16 & 4.45 \\
\hline
\end{tabular}

$* p<0.001(\mathrm{~K}-\mathrm{A})$ 
In ovarian stromal cells a significant increase of the relative volume of smooth membranes in comparison with control animals was found (Table 3). Non-significant decrease of $\mathrm{C}: \mathrm{N}$ ratio in both experimental groups was evident, and the relative volume of nucleus showed slight increase and that of cytoplasm decrease in group A.

Table 3 . Morphometric parameters of the ovarian stromal cells

\begin{tabular}{|c|c|c|c|c|c|}
\hline & $\mathrm{x}(\%)$ & $\mathrm{S}$ & median & $\min$ & $\max$ \\
\hline \multicolumn{6}{|c|}{ Group K (control) } \\
\hline Nucleus & 27.34 & 22.62 & 19.49 & 2.81 & 65.56 \\
\hline Mitochondria & 2.74 & 2.01 & 2.28 & 0.41 & 6.78 \\
\hline Endoplasmic reticulum & 1.27 & 0.65 & 1.27 & 0.40 & 2.30 \\
\hline Smooth membranes & 2.94 & 2.78 & 1.49 & 0.81 & 9.99 \\
\hline Cytoplasm & 65.71 & 19.61 & 71.60 & 32.37 & 88.25 \\
\hline Ratio C:N & 8.38 & 10.08 & 3.81 & 0.49 & 30.40 \\
\hline \multicolumn{6}{|c|}{ Group A (i.p. $1.5 \mathrm{mg} \mathrm{Cd} \cdot \mathrm{kg}^{-1}$ ) } \\
\hline Nucleus & 36.35 & 14.58 & 33.65 & 23.31 & 52.10 \\
\hline Mitochondria & 3.24 & 1.21 & 3.10 & 2.11 & 4.52 \\
\hline Endoplasmic reticulum & 1.11 & 0.29 & 1.08 & 0.84 & 1.41 \\
\hline Smooth membranes & $7.72 *$ & 1.17 & 7.81 & 6.50 & 8.84 \\
\hline Cytoplasm & 51.58 & 14.28 & 54.36 & 36.11 & 64.26 \\
\hline Ratio C:N & 1.69 & 1.03 & 1.62 & 0.69 & 2.76 \\
\hline \multicolumn{6}{|c|}{ Group C (p.o. 1.0 Cd $\cdot \mathrm{kg}^{-1}$ ) } \\
\hline Nucleus & 24.27 & 5.40 & 26.22 & 18.14 & 28.38 \\
\hline Mitochondria & 2.61 & 0.67 & 2.70 & 1.89 & 3.23 \\
\hline Endoplasmic reticulum & 1.09 & 0.40 & 1.08 & 0.70 & 1.49 \\
\hline Smooth membranes & 3.90 & 1.61 & 4.19 & 2.16 & 5.34 \\
\hline Cytoplasm & 68.16 & 4.28 & 67.84 & 64.05 & 72.59 \\
\hline Ratio C:N & 2.95 & 0.93 & 2.59 & 2.26 & 4.00 \\
\hline
\end{tabular}

$* p<0.05(\mathrm{~A}-\mathrm{C}) ; p<0.001(\mathrm{~K}-\mathrm{A})$

Table 4. Morphometric parameters of the ovarian endothelial cells

\begin{tabular}{|c|c|c|c|c|c|}
\hline & $\mathrm{x}(\%)$ & $\mathrm{s}$ & median & $\min$ & $\max$ \\
\hline \multicolumn{6}{|c|}{ Group K (control) } \\
\hline Nucleus & 48.52 & 7.48 & 48.56 & 39.33 & 57.65 \\
\hline Mitochondria & 1.01 & 0.74 & 0.66 & 0.59 & 2.12 \\
\hline Endoplasmic reticulum & 1.07 & 1.02 & 0.63 & 0.42 & 2.58 \\
\hline Smooth membranes & 2.84 & 1.20 & 3.04 & 1.29 & 4.00 \\
\hline Cytoplasm & 46.56 & 7.23 & 46.64 & 37.64 & 55.33 \\
\hline Ratio C:N & 1.00 & 0.31 & 0.96 & 0.65 & 1.41 \\
\hline \multicolumn{6}{|c|}{ Group A (i.p. $1.5 \mathrm{mg} \mathrm{Cd} \cdot \mathrm{kg}^{-1}$ ) } \\
\hline Nucleus & 30.88 & 0.03 & 30.87 & 30.85 & 30.91 \\
\hline Mitochondria & $2.45 *$ & 0.28 & 2.45 & 2.17 & 2.73 \\
\hline Endoplasmic reticulum & 2.22 & 0.40 & 2.22 & 1.82 & 2.61 \\
\hline Smooth membranes & 3.30 & 1.48 & 3.30 & 1.82 & 4.78 \\
\hline Cytoplasm & $61.15^{*}$ & 1.58 & 61.18 & 59.57 & 62.72 \\
\hline Ratio C:N & 1.98 & 0.05 & 1.98 & 1.93 & 2.03 \\
\hline \multicolumn{6}{|c|}{ Group C (p.o. 1.0 Cd·kg-1) } \\
\hline Nucleus & 40.67 & 21.21 & 43.94 & 10.65 & 62.59 \\
\hline Mitochondria & 1.95 & 1.32 & 1.90 & 0 & 3.64 \\
\hline Endoplasmic reticulum & 2.12 & 1.30 & 2.43 & 0.50 & 3.34 \\
\hline Smooth membranes & 1.54 & 0.57 & 1.63 & 0.67 & 2.30 \\
\hline Cytoplasm & 53.72 & 20.60 & 48.49 & 33.81 & 82.46 \\
\hline Ratio C:N & 2.44 & 2.84 & 1.10 & 0.54 & 7.74 \\
\hline
\end{tabular}

$* p<0.05(\mathrm{~K}-\mathrm{A})$ 
In endothelial cells significantly higher amount of mitochondria and cytoplasm in the group A comparing with control was detected (Table 4). The relative volume of nucleus was lower in both experimental groups. On the other hand relative volume of endoplasmic reticulum as well as $\mathrm{C}: \mathrm{N}$ ratio were non-significantly higher in both groups with cadmium administration.

In can be concluded that experimental administration of cadmium clearly affects the structure of various ovarian cells and the effect of this common environmental toxicant is cell-specific.

\section{Discussion}

Results of our study prove negative effects of cadmium on the ovarian structure also on the ultrastructural level. In previous study (Massányi and Uhrín 1996) we have reported that on microscopic level (in the same animals) with regard to the number of follicles, the lowest number of primary follicles was found after i.p. administration of cadmium. Significantly lower numbers of follicles with less than two layers of granulosa cells were found. The number of atretic follicles was significantly higher in all groups administered cadmium. The diameter of the follicles was significanlty smaller in the primary follicles of group C (p.o. administration) in comparison with control group. Percentage of growing follicles was significantly higher and that of stroma significantly lower in the control group in comparison with all experimental groups given cadmium. In in vitro cultured porcine ovarian granulosa cells similar alterations were reported (Massányi et al. 2000). Cell membranes were disintegrated and manifested by the occurrence of vacuoles in the cytoplasm. The vacuoles contained fibrillar or membranous material. The Golgi complex rarely remained intact. Increased number of lysosomes was detected. With increasing cadmium concentration the number of lipid droplets increased. In some cells the changes were less evident and dense mitochondria with distinct membranes were found. In other cell types the amount of mitochondrial matrix increased and that of membranes decreased. Some mitochondria fused with lysosomes. The endoplasmic reticulum rarely remained intact, and its dilatation was well visible on transverse sections. Nuclei with distinct heterochromatin at the nuclear membrane were ofter observed. In accordance with finding in this study, perinuclear cistern in these cells was dilated. Less frequently nuclei with condensed chromatin reminiscent of pyknosis were observed. Some nuclei had dispersed fine granular chromatin.

The stimulatory and inhibitory effects of cadmium on progesterone synthesis were recently investigated using the steroidogenically stable JC-410 porcine granulosa cells line, genetically modified with gene constructs containing the promoter region of the cytochrome P450 side chain cleavage gene linked to a luciferase reporter gene (Henson and Chendrese 2004).

Generally the effetcs of cadmium on reproductive parameters of various animal species are incompletely described. Most of studies describe accumulation of this toxic element in ovaries (Varga et al. 1993; Mas sányi et al. $1995 \mathrm{ab}$ ). On the other hand, ultrastructural observation and specially quantification of toxic effect of cellular structures of various cells is inadequate. In this study we report higher volume of nucleus and lower volume of cytoplasm in almost all experimental groups. Subsequntly, the C:N ratio was decreased mainly in the group with i.p. administration of cadmium. In granulosa and thecal cells we report decrese of the relative volume of mitochondria and smooth membranes in both experimental groups. These results complete the knowledge that cadmium has a dual action in stable porcine granulosa cells as low concentrations activate, whereas high concentrations inhibit progesterone synthesis.

Exposure of human granulosa cells to cadmium resulted in morphological alterations in 
the monolayer depending on dose with longer exposure, cells began to separate from each other by contacting towards the centre and assuming a circular shape (Paksy et al. 1997). In previous experiment with granulosa cell cultures in vitro these cells contained dilated sacks of granular endoplasmic reticulum, vacuolar formations and dilated mitochondria (Mas sányi et al. 2000). In this study major alteration of endoplasmic reticulum were found in thecal and endothelial cells.

Generally, there are few data describing the effect of cadmium on granulosa cells (Henson and Chendrese 2004; Smida et al. 2004; Vršanská et al. 2003; Drbohlav et al. 1998) with mainly monitoring and biochemical aspects of toxicity. In luteal cells only interference of cadmium with steroid biosynthesis in rat luteal cells in vitro was studied (Paksy et al. 1992). In relation to stromal cells in ovary no reports were published. Myeloid and erythroid hematopoietic progenitors and stromal stem cells as possible targets were studied (Van Den Heuvel 2001). The in vitro assays showed that various hematotoxic compounds exert different effects on these cell populations. In vitro exposure of murine bone marrow cells to cadmium indicated that hematopoietic or stromal bone marrow cells were targets. Stromal cells were more affected compared to myeloid cells.

In this study aimed at endothelial cells, we found significantly higher amount of mitochondria and cytoplasm in group A in comparison with control, the relative volume of nucleus was smaller in both experimental group and the relative volume of endoplasmic reticulum and $\mathrm{C}: \mathrm{N}$ ration were non-significantly higher in both groups with cadmium administration. The relation of cadmium to vascular disorders such as atherosclerosis in experimental animals was studied (Kaji 2004). Cadmium destroys the monolayer of endothelial cells and the cytotoxicity is protected by zinc and copper without metallothionein induction. In addition, cadmium reduces endothelial fibrinolytic activity by induction of plasminogen activator inhibitor type 1 synthesis and by inhibition of tissue-type plasminogen activator, respectively. In vascular smooth muscle cells, cadmium can promote their proliferation and influence proteoglycan synthesis and fibrinolysis in different manners. Results indicate that cadmium have specific toxicity in the proliferation, fibrinolysis, and extracellular matrix formation of vascular endothelial and smooth muscle cells. Endotelial alterations of cadmium are described mainly in liver, causing an inflammatory processes that plays a major role in the secondary injury of the liver, and infiltration of neutrophils at the site of necrosis is a common observation (Mousa 2004).

\section{Ultraštrukturálne zmeny vaječníka králika po podaní kadmia}

V práci sa sledoval vplyv kadmia ako rizikového faktora životného prostredia na ultraštruktúru ovariálnych buniek králika. Hodnotili sa kvalitatívne a kvantitatívne zmeny jednotlivých bunkových organel. Kvalitatívna analýza buniek stratum granulosum preukázala unduláciu jadrovej membrány, dilatáciu perinukleárneho priestoru a endoplazmatického retikula. Pri analýze tékalnych buniek bola najcharakteristickejšia dilatácia endoplazmatického retikula. Bola pozorovaná aj dilatácia perinukleárnej cisterny. V bunkách strómy sme zistili výraznú dilatáciu perinukleárnej cisterny a štruktúr s hladkými membránami. Endoteliálne bunky prejavovali znaky dilatovaných mitochondrií s poškodenou vnútornou štruktúrou a chýbali prevažne kristy.

Kvantitatívnou analýzou sme zistili preukazný pokles $(p<0,05)$ relatívneho objemu mitochondrií v skupine $\mathrm{C}$ (s dlhodobou perorálnou aplikáciou kadmia) v porovnaní so skupinou A (intraperitoneálne podanie kadmia) V bunkách stratum granulosum. V tékalnych bunkách sa zistilo preukazné $(p<0,001)$ zvýšenie relatívneho objemu endoplazmatického retikula $\mathrm{v}$ skupine $\mathrm{A} \mathrm{v}$ porovnaní s kontrolnou skupinou. V bunkách strómy vaječníka sme sledovali preukazné $(p<0,05)$ zvýšenie relatívneho objemu hladkých membrán v oboch pokusných skupinách v porovnaní s kontrolou. Endoteliálne bunky mali 
preukazne $(p<0,05)$ vyšší objem mitochondrií po podaní kadmia (skupina A) v porovnaní s kontrolou, čo je spôsobené dilatáciou existujúcich mitochondrií.

Dosiahnuté výsledky popisujú štrukturálne zmeny buniek vaječníka po podaní kadmia. Zistil sa negatívny účinok tejto toxickej látky vo všetkých sledovaných typoch buniek s miernymi štrukturálnymi variáciami, čo potvrdzuje, že účinok kadmia je závislý od typu bunky na ktorú pôsobí.

\section{Acknowledgements}

This study was supported with VEGA grant No. 1/9080/02 and 1/2417/05 of the Slovak Ministry of Education. We would like to express our gratitude to Ing. Zuzana Štulrajterová and Ing. Peter Čupka for technical assistance.

\section{References}

DRBOHLAV, P, BENCKO, V, MASATA, J, BENDL, J, REZACOVA, J, ZOUHAR, T, CERNY, V, HALKOVA, E 1998: Detection of cadmium and zinc in the blood and follicular fluid in women in the IVF and ET program. Česká Gynekol 6: 292-300

HENSON, MC, CHENDRESE, PJ 2004: Endocrine disruption by cadmium, a common environmental toxicant with paradoxical effects on reproduction. Exp Biol Med 229: 383-392

FRIBERG, L, NORDBERG, GF, VOUK, V 1986. Handbook on the toxicology of metals. Elsevier, Amsterdam, 1986, pp. 130-184

KAJI, T 2004: Cell biology of heavy metal toxicity in vascular tissue. Yakugaku Zasshi 124: 113-120

KAR, AB, DAS, RP, KARKUN, JN 1959: Ovarian changes in prepubertal rats after treatment with cadmium chloride. Acta Biol Med Germ 3: 372-399

MERIAN, M 1991. Cadmium and their compounds in the environment. VCH, Weinheim, NY, Basel, Cambridge, pp. 803-851

MASSÁNYI, P, TOMAN, R, UHRÍN, V, RENON, P 1995a: Distribution of cadmium in selected organs of rabbits after an acute and chronic administration. Ital J Food Sci 7: 311-316

MASSÁNYI, P, TOMAN, R, NAJMIK, F 1995b: Concentrations of cadmium in ovary, oviductus, uterus, testis and tunica albuginea of testis in cattle. J Environ Sci Health A30: 1685-1692

MASSÁNYI, P, UHRÍN, V 1996: Histological changes in the ovaries of rabbits after an administration of cadmium. Reprod Dom Anim 31: 629-632

MASSÁNYI, P, UHRÍN, V 1997: Histological changes in the uterus of rabbits after an administration of cadmium. J Environ Sci Health A32: 1459-1466

MASSÁNYI, P, UHRÍN, V, TOMAN, R, KOVÁČIK, J, BÍRO, D 1999: Histological changes in the oviduct of rabbits after administration of cadmium. J Anim Feed Sci 7: 255-261

MASSÁNYI, P, UHRÍN, V, SIROTKIN, AV, PAKSY, K, FORGÁCS, ZS, TOMAN, R, KOVÁČIK, J 2000: Effects of cadmium on ultrastructure and steroidogenesis in cultured porcine ovarian granulosa cells. Acta Vet Brno 69: 101-106

MOUSA, SA 2004: Expression of adhesion molecules during cadmium hepatotoxicity. Life Sci 75: 93-105

PAKSY, K, VARGA, B, LÁZÁR, P 1992: Cadmium interferes with steroid biosynthesis in rat granulosa and luteal cells in vitro. BioMetals 5: 245-250

PAKSY, K, RAJCZY, K, FORGACS, ZS, LÁZÁR, P, BERNARD, A, GÁTI, I, KAÁLI, GS 1997: Effects of cadmium on morphology and steroidogenesis of cultured human ovarian granulosa cells. J Appl Toxicol 17: 321-327

SMIDA, AD, VALDERRAMA, XP, AGOSTINI, MC, FURLAN, MA, CHENDRESE, J 2004: Cadmium stimulates transcription of the cytochrome $\mathrm{P} 450$ side chain cleavage gene in genetically modified stable porcine granulosa cells. Biol Reprod 70: 25-31

TOMAN, R, MASSÁNYI, P, UHRÍN, V 2002: Changes in the testis and epididymis of rabbits after an intraperitoneal and peroral administration of cadmium. Trace Elem Electrolytes 19: 114-117

VAN DEN HEUVEL, RL, LEPPENS, H, SCHOETERS, GE 2001: Use of in vitro assays to assess hematotoxic effects of environmental compounds. Cell Biol Toxicol 17: 107-116

VRŠANSKÁ, S, NAGYOVÁ, E, MLYNARČIKOVÁ, A, FICKOVA, M, KOLENA, J 2003: Components of cigarette smoke inhibit expansion of oocyte-cumulus complexes from porcine follicles. Physiol Res 52: 383-387

WEIBEL, ER, KISTLER, GS, SCHERLE, WF 1966: Practical stereological methods for morphometric cytology. J Cell Biol 30: 23-28

ŽITNÝ, J, MASSÁNYI, P, TRAKOVICKÁ, A, RAFAJ, J, TOMAN, R 2004: Quantification of the ovarian follicular growth in rabbits. Bull Vet Instit Pulawy 48: 37-40 
Plate I

Massányi, P.: Ultrastructural Changes ... pp. 29-35

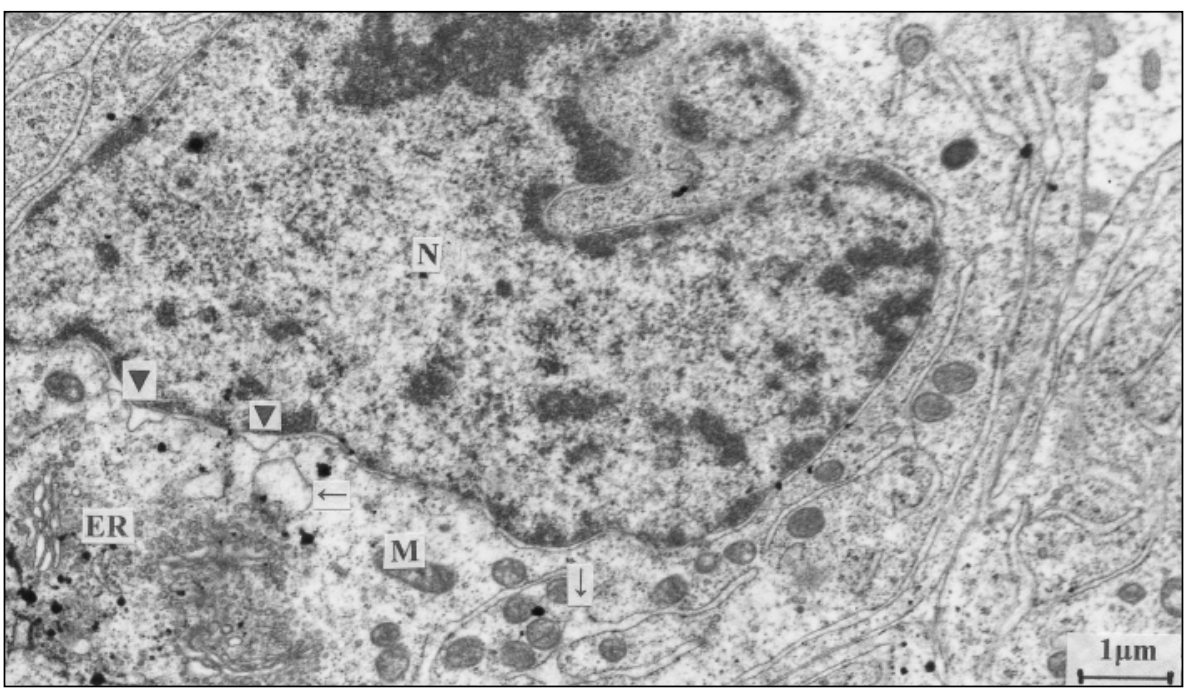

Fig. 1. In granulosa cells undulation of nuclear membrane $(\boldsymbol{\nabla})$ enclosing the nucleus $(\mathrm{N})$ and dilatation of perinuclear cistern. Endoplasmic reticulum (ER) was dilated (arrow); mitochondria (M). [× 7200]

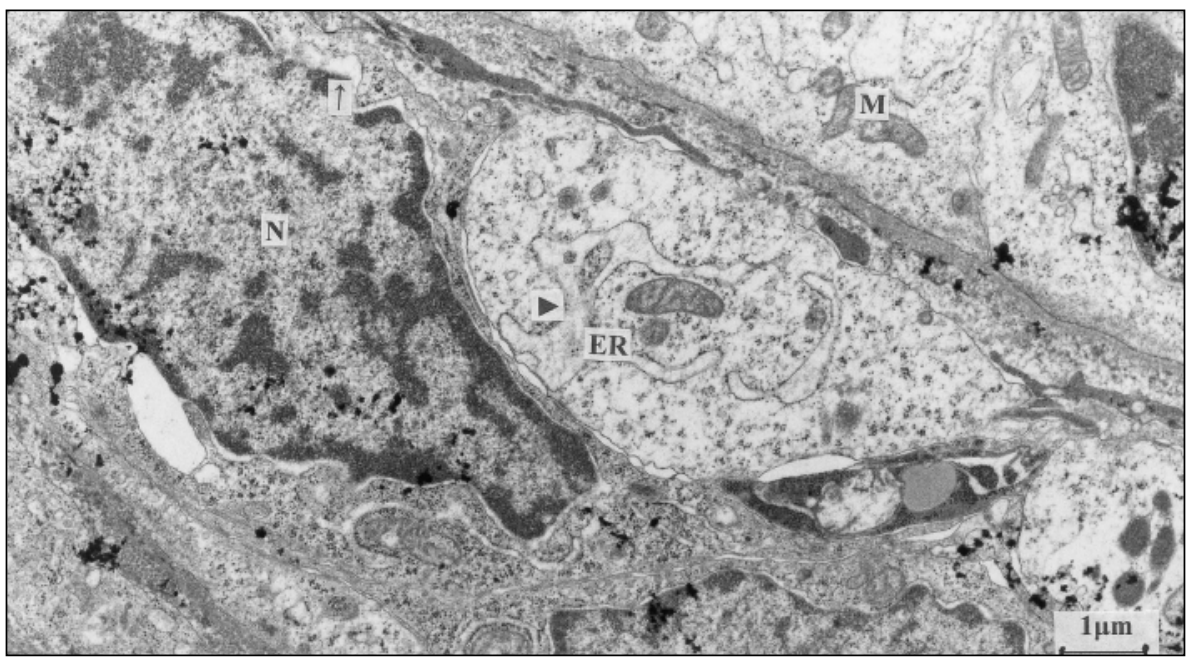

Fig. 2. In ovarian theca cells dilatation of endoplasmic reticulum (ER) was the most characteristic sign of cadmium related alterations $(\boldsymbol{\nabla})$. Dilatation of perinuclear cistern was evident (arrow). Nucleus $(\mathrm{N})$ and mitochondria (M). [× 7200] 


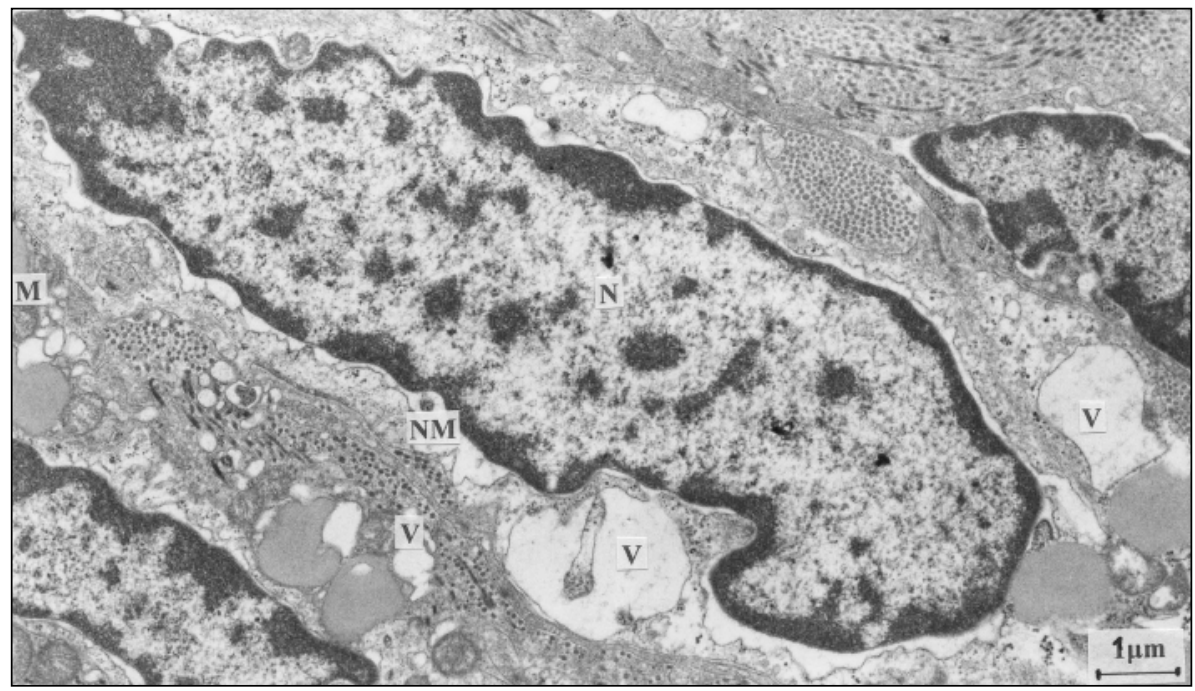

Fig. 3. Intensive alterations of nuclear membrane (NM) with dilatation of perinuclear cistern and dilated structures with smooth membranes - vacuolisation $(\mathrm{V})$ is a specific sign of cadmium toxicity in ovarian stromal cells. Nucleus (N) and mitochondria (M). [× 7200]

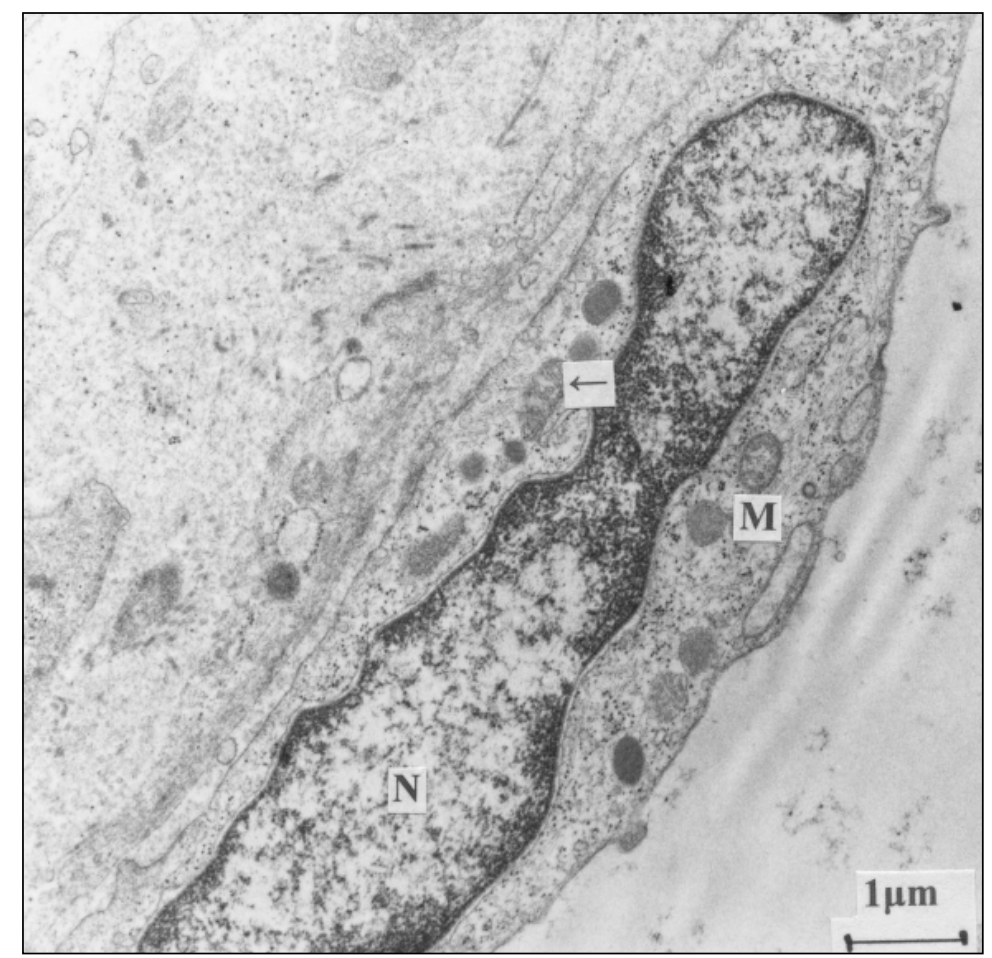

Fig. 4. In endothelial cells dilated mitochondria (M) with altered inner structure (arrow), mainly missing cristae were found after cadmium administration. Nucleus $(\mathrm{N})$ and mitochondria $(\mathrm{M}) .[\times 7200]$ 